\title{
AGRICULTURE \\ OF GREATER SOCHI FROM THE ENEOLITHIC TO THE MIDDLE AGES BASED ON ARCHAEOLOGICAL AND HISTORICAL SOURCES
}

\author{
Kizilov A. S., Platonov A. P. \\ Federal Research Centre the Subtropical Scientific Centre \\ of the Russian Academy of Sciences, \\ Sochi,Russia,e-mail: kiziloff2014@mail.ru; platonov2014@yandex.ru
}

The territory of Greater Sochi is one of the oldest regions in the Russian Federation where crop production originated. The available archaeological sites give numerous confirmations. The loss of a number of these monuments during urbanization, of course, deprives science of the opportunity to study the processes of agricultural development in the region more deeply. However, the materials preserved from the lost monuments and from the newly discovered ones allow us to get a relatively objective picture of agriculture genesis on the territory of Greater Sochi. The paper describes some historical stages and directions in the development of agricultural crops and tillage technologies from the Eneolithic to the early Middle Ages, and presents the reasons for the change in the area of agricultural land cultivation. The analysis and results of experimental approbation of agricultural implements are given. The genesis of crop production is considered in the context of historical changes in political, technological and climatic conditions.

Key words: genesis of agriculture, hoe farming, archaeological sites, experimental approbation, Bronze Age, antiquity, colonization, settlement structure.

\section{РЕЗУЛЬТАТЫ ИНТРОДУКЦИИ \\ СУБТРОПИЧЕСКИХ, ЮЖНЫХ ПЛОДОВЫХ И ЦВЕТОЧНО-ДЕКОРАТИВНЫХ КУЛЬТУР В ФИЦ СНЦ РАН В 2020 Г.}

\author{
Рындин А. В., Кулян Р. В., Слепченко Н. А., Тутберидзе Ц. В., Горшков В. М. \\ Федеральное государственное бюджетное учреждение науки \\ «Федеральный исследовательский иентр «Субтропический научный иентр \\ Российской академии наук», \\ 2. Сочи, Россия, e-mail: slepchenko@vniisubtrop.ru
}

В статье приведены результаты исследований Федерального государственного бюджетного учреждения науки «Федеральный исследовательский центр «Субтропический научный центр Российской академии наук» по тематике мобилизации, сохранения и изучения генетических биоресурсных коллекций. Геноресурсная коллекция субтропических, южных плодовых и цветочно-декоративных культур сохранена в количестве 2650 сортообразцов. В результате исследований, проведённых в 2020 г. на различных коллекциях плодовых культур выделены группы по срокам созревания. Цветочно-декоративные 
культуры представлены в родовом и видовом разрезе, сгруппированы по срокам цветения, окраске цветка. Решение поставленных задач даст возможность дальнейшему развитию отечественного садоводства и цветоводства, позволит расширить вопросы продовольственной безопасности и импортозамещения.

Ключевые слова: интродукция, сортоизучение, геноресурсная коллекция, субтропические, южные плодовые и цветочно-декоративные культуры.

Интерес к интродукции растений и к биоресурсным коллекциям возрастает во всех странах мира. Успехи в создании сортов и гибридов различного направления в значительной мере зависят от многообразия исходного генетического материала.

Одним из важных направлений исследований Федерального государственного бюджетного учреждения науки «Федеральный исследовательский центр «Субтропический научный центр Российской академии наук» (г. Сочи) является создание, пополнение и поддержание генетических коллекций субтропических, южных плодовых и цветочно-декоративных культур. Обогащение коллекций идёт путём интродукции, т. е. привлечения видов и сортов из других географических районов, в том числе из-за рубежа, их испытания и выделения наиболее перспективных для возделывания в регионе или использования в селекционном процессе, для создания сортов, приспособленных к местным условиям [8, 9, 13, 21, 26-29, 35-37, 39, 42-44, 50, 51, 53, 55, 56].

Субтропическая зона Черноморского побережья России является наиболее благоприятной для возделывания таких теплолюбивых культур, как цитрусовые, актинидия, фейхоа, хурма, чай, азимина и др., многие из которых не встречаются за её пределами $[1,2,35]$. На протяжении последних десятилетий отмечалась переориентация целевого использования данных территорий за счёт развития объектов рекреационного комплекса на фоне масштабных сокращений площадей, используемых для нужд сельского хозяйства. Одним из путей решения данной проблемы является расширение ареалов возделывания субтропических культур, что позволит сохранить уникальные виды и сорта хозяйственно-ценных растений и удовлетворить потребности населения в продукции за счёт отечественных производителей, что особенно актуально с точки зрения обеспечения продовольственной безопасности нашей страны.

Коллекция цитрусовых культур представлена генетическим и эколого-географическим разнообразием сортов мандарина, лимона, апельсина, грейпфрута и других, интродуцированных из Японии, Америки, Италии, Испании, Никарагуа, Абхазии [5, 20, 40]. 
Возделывание цитрусовых культур в России ограничивается южной частью Черноморского побережья Краснодарского края, где господствует влажный субтропический климат. Главным лимитирующим фактором, сдерживающим широкое развитие цитрусовых в регионе, является низкая зимостойкость существующего сортимента и поздние сроки созревания [38].

В качестве приоритетных направлений стоит отметить научное обеспечение отрасли чаеводства. Данная работа проводится с начала прошлого века. Восстановление насаждений в субтропической зоне и распространение культуры чая за её пределами представляет как научную, так и практическую ценность [23, 54].

В рамках импортозамещения и развития отечественного цветоводства сохраняются и поддерживаются коллекции цветочно-декоративных культур, разрабатываются их сортименты. Привлекаются новые декоративные растения, проводятся исследования и оценка их устойчивости в условиях влажных субтропиков, разрабатываются технологии выращивания. Спрос на срез цветов и местный посадочный материал постоянно растёт. Большой блок в работе Центра занимают селекционные исследования, создаются новые высокодекоративные, более устойчивые, продуктивные сорта [3, 4, 6, 7, 12, 14-17, 30-32, 45, 49, 57].

В настоящее время особый интерес представляют вопросы озеленения скверов и парков. Создание высокодекоративных зелёных насаждений и посадок в условиях урболандшафта должно базироваться на научной основе с учётом экологических особенностей озеленяемых территорий и разработанного для них ассортимента растений. Поэтому большое внимание уделяется интродукции в регион новых объектов для ландшафтного строительства [18, 19, 22, 24, 25, 41].

В процессе изучения сортообразцов при интродукции и селекции разрабатываются и усовершенствуются методы и методики оценки субтропических, южных плодовых и цветочно-декоративных культур $[10,11,46-48,52]$.

Актуальность исследований состоит в том, что на базе ФИЦ СНЦ РАН созданы генетические коллекции, как культурных видов растений, так и их диких сородичей, которые позволяют сохранить хозяйственно-ценные виды и формы, являющиеся объектами разносторонних исследований, способствующих углубленному изучению эколого-биологических особенностей, разработке новых технологических приёмов возделывания и выделению исходного материала для дальнейшей селекционной работы. Что, в свою очередь, учитывая уникальность коллекционных объектов, позволяет получить новые районированные сорта, отличающиеся высокой устойчивостью и продуктивностью. 
Цель работы заключается в сохранении и пополнении генофонда субтропических, южных плодовых и цветочно-декоративных культур для выделения и создания источников хозяйственно-ценных признаков, в том числе устойчивости к биотическим и абиотическим стрессорам; получении экспериментальных данных, позволяющих оценить возможность расширения ареала субтропических культур - унаби, хурмы, азимины и чая в более северные регионы для увеличения площади их возделывания, а также для разработки научно-обоснованных сортиментов и эффективных методов оценки изучаемых культур.

Исследования проводились на опытной базе ФИЦ СНЦ РАН по общепринятым, классическим, а также разрабатываемым на их основе современным методам и методикам $[11,33,47]$. Объектами исследований являлись коллекции субтропических, южных плодовых и цветочно-декоративных культур.

Коллекции Центра на конец 2020 г. насчитывали 2650 сортообразцов цветочно-декоративных, субтропических и южных плодовых культур. Большинство видов и культур поддерживаются в живом виде в полевых условиях.

Сорта цитрусовых, хурмы восточной, фейхоа, чая, изучаемые в Центре, пользуются особой популярностью и спросом не только среди профессионалов, но и любителей.

На сегодняшний день коллекция цитрусовых Центра, одна из самых полных в Российской Федерации, насчитывает 136 сортообразцов (рис. 1). В ней содержатся как зимостойкие экземпляры-C. unshiu 'Черноморский', C. unshiu, гибрид $3252 \times$ citrangequat $(C$. sinensis $\times$ P. trifoliata $\times$ Fortunella margarita), $C . \times$ insitorum $(C$. sinensis $\times P$. trifoliata), $C . \times$ insitorum, так и теплолюбивые средиземноморские сорта мандарина 'Tardio', 'Rage', отличающиеся повышенным содержанием сахара, сильным ароматом.

Лимонная группа представлена интересными образцами: 'Диоскурия', 'Одиши', полученными путём межродовой гибридизации, ремонтантными: C. limon 'Del Brasil', $C . \times$ limetta,$C . \times$ meyeri, $C . \times$ limonelloides ('Кантонский'), C. × ponderosa, C. × bergamia, C. $\times$ aurantifolia. В коллекции сохраняются пёстролистные образцы -C. microcarpa variegata, C. medica var. variegata.

Для промышленного и любительского цитрусоводства выделен ряд раннеспелых, бессемянных сортов мандарина: 'Miyagawa Wase', 'Kowano-Wase', 'Юбилейный', 'Ochi Wase', 'Крупноплодный'; лимона: 'Eurika', 'Lisbon', 'Новоафонский’, 'Ударник', 'Одиши', ‘Диоскурия’. Для декоративного направления: $C$. × aurantifolia, $C$. $\times$ bergamia, C. $\times$ limetta, $C . \times$ limonelloides, $C . \times$ ponderosa. 


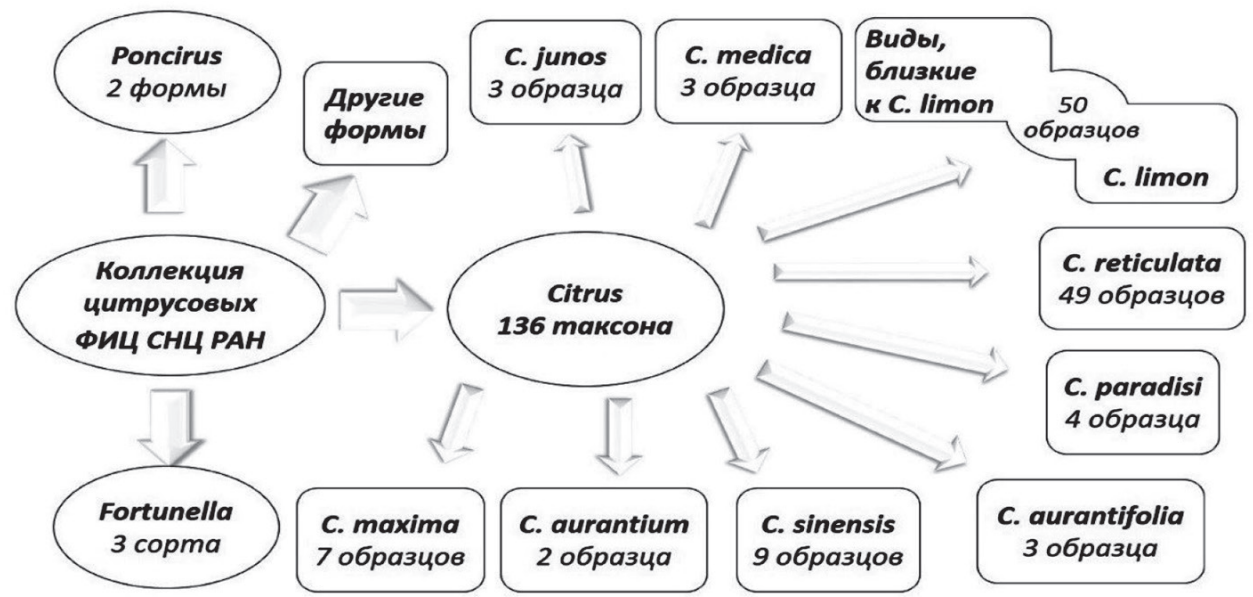

Рис. 1. Состав коллекции цитрусовых

Коллекция фейхоа немногочисленна, состоит из 12 сортообразцов, в том числе трёх сортов селекции Центра: 'Дагомысская', 'Дачная', 'Сентябрьская', районированного 'Superba', выделенных перспективных форм и формы № 20 из Абхазии. Сорта и формы сгруппированы по срокам созревания на три группы: раннего срока созревания (II-III декады сентября - I декада октября): 'Сентябрьская', 4-10, 12-5, ШВ-1, 13-11, 'Дачная', среднего (II-III декады октября - I декада ноября): 'Superba', 'Дагомысская', 10-22, Б-13 и позднего (ноябрь - начало декабря): 6-24.

Хурма восточная насчитывает 23 сортообразца, в том числе два сорта селекции Центра ('Хостинский’ и 'МВГ Омарова'), один гибрид (№ 39 проходит сортоиспытание). Сорта в коллекции сгруппированы по качеству плодов (табл. 1). Выделены группы по срокам созревания: ранние (сентябрь-октябрь) - 47 \%, средние (октябрь-ноябрь) - $24 \%$, поздние (ноябрьдекабрь) - 29 \%. По силе роста лидируют среднерослые сорта (3,0-4,0 м) - 59 \%, сильнорослые $(4,0-5,0$ м) - 24 \%, низкорослые (до 3,0 м) - 17 \%.

Таблица 1

Классификация сортов хурмы восточной по качеству плодов

\begin{tabular}{|c|c|c|}
\hline Группа & Сорт, гибрид & $\begin{array}{l}\text { Кол-во, } \\
\text { шт. }\end{array}$ \\
\hline Терпкие & 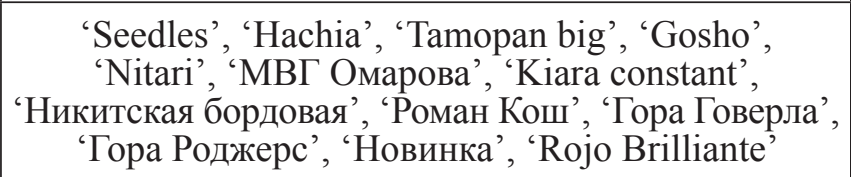 & 13 \\
\hline Нетерпкие & 'Djiro', 'XX Century', 'Fuyu', 'Geili' & 4 \\
\hline $\begin{array}{l}\text { Варьиру- } \\
\text { ющие }\end{array}$ & $\begin{array}{l}\text { 'Хостинский', 'Hiakume', 'Zenji-Maru’, ‘ } \\
\text { Kuro-Kuma', 'Киара варьирующая’, гибрид № } 39\end{array}$ & 6 \\
\hline
\end{tabular}


Коллекция фундука включает 30 сортообразцов, в том числе десять высокопродуктивных устойчивых сортов селекции Центра ('Перестройка', 'Сочи-1', 'Сочи-2', 'Кубань', 'Карамановский', 'Кавказ’, 'Кристина', 'Виктория', 'Галина', 'Анастасия'), которые возделываются на разных коллекционных участках, в том числе в с. Раздольное и п. Цветочный (Адыгейский филиал). Коллекция сгруппирована по срокам созревания: доля ранних (І декада июля) составляет $40 \%$, средних (III декада июля) - 43 \% и поздних (І декада августа) - 17 \%.

Генофонд чая состоит из 24 сортообразцов, в том числе семи ('Колхида', 'Каратум', 'Сочи', 'Мацестинский', 'Адыгейский', 'Вано', 'Южанка') селекции Центра, а также высокоурожайных, зимостойких форм на основе 'Кимынь', и сортов грузинской селекции, созданных путём мутогенеза. Из коллекции выделены 'Колхида', 'Грузинский № 15', 'Каратум', отличающиеся высоким побегообразованием и ранним сроком сбора флешей.

В настоящее время продолжается изучение коллекции персика, состоящей из 69 сортообразцов. Исследования направлены, прежде всего, на выделение поздних сортов, которых недостаточно в товарном производстве. Продолжены наблюдения за сортами итальянской селекции: 'Bolero', 'Peva Trevel', 'Cesarini', 'San Varano', 'Venus', 'K-2', 'Gladis', 'Michelini', 'Bellaqe Cesana', 'Eleqant Lady', полученными в рамках договора о научном сотрудничестве с научным центром по сельскохозяйственным культурам г. Чезена, Италия. Среди коллекционных образцов персика выделены группы по срокам созревания. Группа сверхранних и ранних сортов составляет $35 \%$, среднего - $32 \%$ и позднего - $22 \%$, сорта подвои - $11 \%$.

Коллекция яблони состоит из 66 сортообразцов и включает четыре сорта селекции Центра ('Южное', 'Петропавловское', 'Раздольное' и 'Черноморское Инденко'), большинство из которых относительно устойчивы к парше и мучнистой росе. Коллекция сгруппирована по срокам созревания: летнего - $36 \%$, осеннего - $30 \%$ и зимнего - $34 \%$.

Генофонд груши состоит из 28 сортообразцов, из которых - 25 сортов и 3 формы (группа груши обыкновенной (Pyrus communis L.) - 26 образцов, восточноазиатской (Pyrus serotina Rehd.) - 2. Коллекция сгруппирована по срокам созревания: ранне-летние (III декада июля) - 14 \%, летние (III декада августа) $-36 \%$ и осенне-зимние (II-III декада сентября и позже) $-50 \%$.

Коллекция актинидии состоит из сортов актинидии сладкой (Actinidia deliciosa) (11 интродуцированных и 2 сорта селекции Центра ('Монти C' и 'Хейворд Российский') и сорта A. arguta ('Земляничная’). Сгруппирована по срокам созревания: ранние (октябрь) - 2 сорта, средние (начало ноября) - 2 и поздние (конец ноября) - 7, а также два сорта-опылителя. 
Глава 1. Общие вопросы

Коллекция инжира включает 16 сортообразцов, в том числе два селекции Центра ('Сочинский-15' и 'Сочинский-4'). Коллекция граната состоит из 12 сортов. Коллекция сливы русской (алычи) - из 13.

Генофонд унаби насчитывает 17 сортообразцов. Выделено шесть крупноплодных сортов, два ('Та-ян-цзао', 'У-син-хун') - склонных к партенокарпическому плодоношению, а также отмечены наиболее урожайные: 'Та-ян-цзао', 'Южанин', 'Бурним’, 'Вахш', 'У-син-хун', 'Гиссарский'.

Коллекция азимины представлена сортами, созданными в Центре - 'Сочинская-11', 'Сочинская-12', 'Валентина' и 'Осенний сюрприз’.

Генетическая коллекция субтропических и южных плодовых культур в 2020 г. пополнилась тремя сортами груши: 'Дюшес летний', 'Медовая' и 'Декора'; сортом алычи азербайджанской селекции 'Реджебли'; четырьмя сортами персика: 'Золотой юбилей', 'Осенний румянец', 'Память Симиренко', 'Пятница-13', тремя сортами нектарина: 'Орион', 'Обильный', 'Silver Roma' и клоновыми подвоями косточковых культур: 'БП', 'Бест', 'ВВА-1', 'Упрямец'. Коллекция инжира пополнена сортами из Никитского ботсада: 'Безуль Эль Кадель', 'Рандино', 'Сан Педро чёрный', ‘Зелёный’, ‘Жёлтоплодный урожайный’.

Генофондовая коллекция цветочно-декоративных культур включает луковичные и клубнелуковичные растения, многолетние травянистые, виды природной флоры, красивоцветущие кустарники и другие.

Коллекция Ирисов насчитывает 254 сортообразца (рис. 2), основу которой составляет ирис гибридный (Iris hybrida hort.) - 82 \%, ирис сибирский (Iris sibirica L.) - 10 \%, ирис мечевидный (Iris ensata Thunb.) - 3 \%, ирис спурия (I. spuria) - 1,5 \%. Доля видовых ирисов - 3,5 \% (ирис мечевидный (I. ensata Thunb.), и. сибирский (I. sibirica L.), и. ненастоящий (I. notha Bieb.), и. колхидский (I. colchica Kem.-Nath.), и. ложноненастоящий (I. pseudonotha Galushko), и. Монье (I. monnieri Dcjuss.), и. бледный (I. pallida Lam.), и. карликовый (I. pumila L.) и и. японский (I. japonica Thunb.).

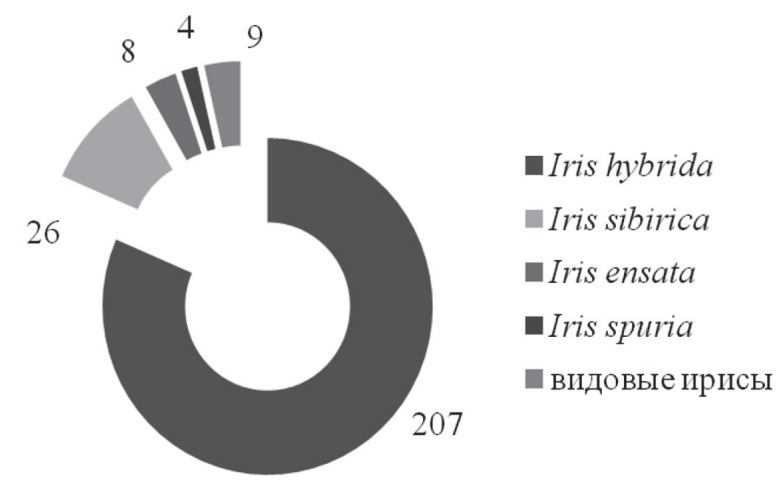

Рис. 2. Состав коллекции ирисов 
В 2020 г. проводилось сортоизучение на 21 образце ириса сибирского. Проведены фенологические наблюдения, биометрические измерения, оценка декоративности. В результате подсчётов установлено, что практически у всех сортообразцов высокий балл декоративности. Наибольшие баллы - 58,80 у 'Kita-No-Seisa', 58,60 - 'Double Standards', 57,80 - 'Бийские перекаты', наименьший - 44,00 у 'Стерха'. Отмечено снижение показателей декоративности у 'Mountain Lake', получившего в 2019 г. один из высоких баллов $(53,01)$, а в текущем году $(47,90)$. В результате проведённых фенологических наблюдений выделены сорта по срокам цветения. Раннее цветение отмечено у Iris sibirica, 'Aqua Whispers', 'Lee’s Blue', позднее у ‘Блики'.

Коллекция роз насчитывает 97 сортообразцов (рис. 3), отечественной и зарубежной селекции из 15 групп. Сорта распределены по функциональным группам: доля крупноцветковых роз составляет $28 \%$, кустовых - $26 \%$, многоцветковых - $15 \%$, почвопокровных - 4 \%, плетистых $-27 \%$.

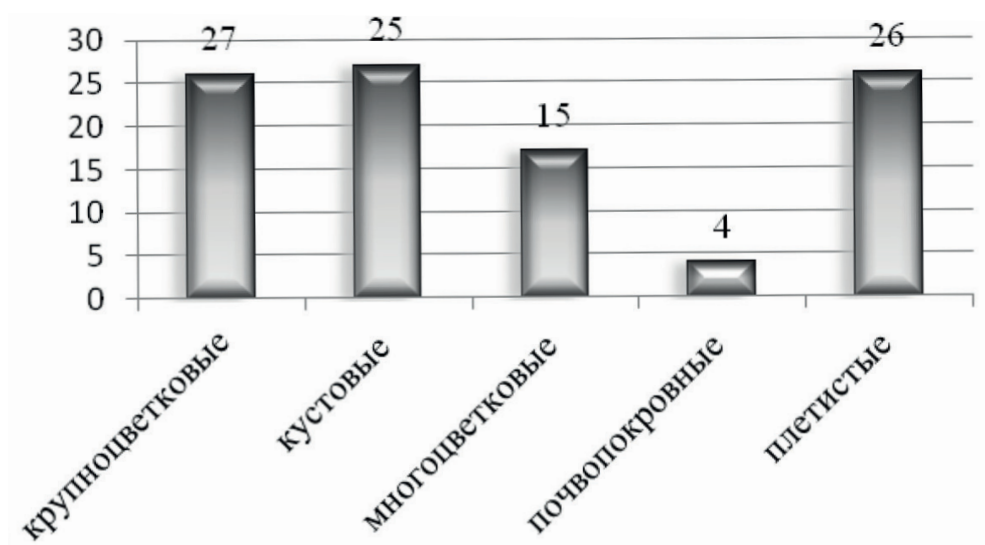

Рис. 3. Состав коллекции роз

В 2020 г. в рамках сортоизучения проводились исследования на 26 сортообразцах роз из функциональной группы плетистые, которые были сгруппированы по окраске. Экземпляры с розовой окраской, в том числе с учётом гармоничных переходов от бледно-розового до насыщенно-розового составляют 38 \%. Сорта с оранжевой, белой и жёлтой окраской - примерно по 18 \%. Лилово-фиолетовый и красный сорта - по 4 \%.

Коллекция луковичных и клубнелуковичных культур состоит из представителей 4 семейств, 23 родов, 261 сортообразца (табл. 2), в 2020 г. пополнилась новыми сортообразцами: Tulbaghia violacea Harv., Haemanthus albiflos Jacq., Ornithogalum magnum Krasch. \& Schischk, Iris reticulata 'Pauline' и 4 видами луков - Allium ascalonicum L., A. ramosum L. $=$ A. odorum L., Allium cyrilli Ten., Allium nigrum L. 
Таблий 2

Состав коллекции луковичных и клубнелуковичных культур

\begin{tabular}{|c|c|c|}
\hline Семейство & Род & $\begin{array}{c}\text { Количество } \\
\text { сортов } \\
\text { (видов), } \\
\text { шт. }\end{array}$ \\
\hline Liliaceae Juss. & Tulipa L. & 80 \\
\hline \multirow{4}{*}{ Iridaceae Juss. } & Xiphium Mill. & 16 \\
\hline & Crocus L. & 24 \\
\hline & Gladiolus L. & 23 \\
\hline & Iridodictium Rodion. & 3 \\
\hline \multirow{14}{*}{$\begin{array}{c}\text { Amaryllidaceae Jaume } \\
\text { Saint-Hilaire }\end{array}$} & Allium L. & 5 \\
\hline & Narcissus L. & 39 \\
\hline & Leucojum L. & 1 \\
\hline & Pancratium L. & 1 \\
\hline & Sternbergia Waldst.\&Kit. & 1 \\
\hline & Hippeastrum Herb. & 27 \\
\hline & Nerine Herb. & 4 \\
\hline & Lycoris Herb. & 3 \\
\hline & Zephyranthes Herb. & 2 \\
\hline & Amaryllis L. & 2 \\
\hline & Habranthus Herb. & 2 \\
\hline & Cyrtanthus Aiton & 1 \\
\hline & Tulbaghia L. & 1 \\
\hline & Haemanthus L. & 1 \\
\hline \multirow{5}{*}{ Asparagaceae Juss. } & Muscari Mill. & 19 \\
\hline & Hyacinthus orientalis L. & 2 \\
\hline & Scilla L. & 1 \\
\hline & Ornithogalum L. & 3 \\
\hline & ВСЕГО: & 261 \\
\hline
\end{tabular}

В 2020 г. коллекция рода Pelargonium, состоящая из 200 сортообразцов, пополнилась на 6 образцов - три сорта крупноцветковой пеларгонии с ценными высокодекоративными признаками (продолжительно-цветущие, компактные и устойчивые): два сорта селекции Центра - 'Кармен Сюита' и 'Фламенко' и сорт английской селекции — 'Violet' (copтосерии Candy Flowers). Кроме того, коллекция пополнилась новыми сортами пеларгонии курчавой селекции Центра: 'Неженка', ‘Лучистая' и 'Чародейка'.

Коллекция декоративных культур зимнего сада насчитывает 156 сортообразцов, относящихся к 40 семействам, 97 родам (рис. 4). В 2020 г. коллекция пополнена 4 видами: каланхоэ Федченко (Bryophyllum fedtschenkoi 
(Raym.-Hamet \& H. Perrier) Lauz.-March) из Crassulaceae J. St.-Hil.; молочаем красивейшим (Пуансеттией) (Euphorbia pulcherrima Willd. ex Klotzsch.) из Euphorbiaceae Juss.; муррайей метельчатой (Murraya paniculata (L.) Jack.) из Rutaceae Juss.; флебодиумом золотистым (Phlebodium aureum (L.) J. Sm.) из Polypodiaceae J. Presl \& C. Presl.

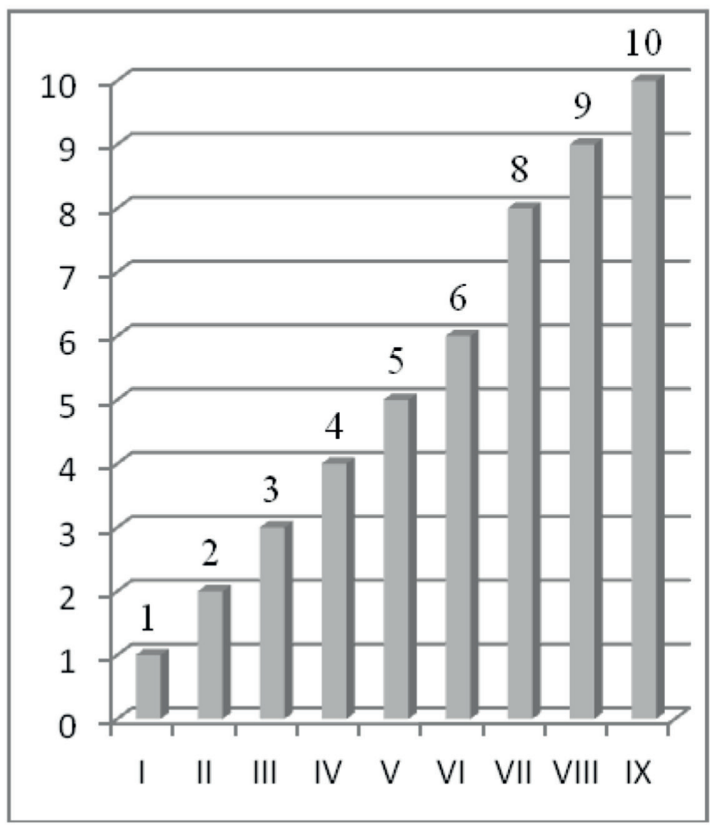

Рис. 4. Состав коллекции Зимнего сада по семействам

\section{Примечание:}

I группа - семейства, имеющие в составе 1 вид: Anacardiaceae, Aspleniaceae, Asteraceae, Convolvulaceae, Lauraceae, Oleaceae, Onagraceae, Orchidaceae, Oxalidaceae, Pandanaceae, Polypodiaceae, Rutaceae, Solanaceae.

II группа - семейства, включающие по 2 вида: Apocynaceae, Cyperaceae, Davalliaceae, Geraniaceae, Gesneriaceae, Lamiaceae, Malvaceae, Urticaceae, Xanthorrhoeaceae.

III группа - Amaryllidaceae, Araliaceae, Asphodelaceae, Pipiraceae, Vitaceae - по 3 вида.

IV группа - Marantaceae - 4 вида.

V группа - Acanthaceae, Arecaceae, Bromeliaceae Pteridaceae по 5 видов.

VI группа - Euphorbiaceae - 6 видов.

VII группа - Moraceae, Commelinaceae - по 8 видов.

VIII группа - Begoniaceae - 9 видов.

IX группа - Cactaceae, Araceae, Asparagaceae - более 10 видов. 
В коллекции Центра сохраняется коллекция видов природной флоры, состоящая из 142 дикорастущих видов, относящихся к 104 родам и 56 семействам (рис. 5). Подавляющее большинство видов являются многолетними травянистыми растениями, обладают высокими декоративными качествами. Изучение особенностей роста и развития растений из коллекции видов природной флоры дало возможность оценить их потенциал, наметить перспективные направления дальнейших испытаний. Культивары, получившие высокие баллы перспективности: обладающие декоративными качествами, хорошими показателями способности к размножению, устойчивые к болезням и вредителям могут быть использованы по разным направлениям, в том числе в поддержании генетических коллекций и сохранении биоразнообразия, сортоизучении, селекционных исследованиях, разработке технологий возделывания. Однако не стоит оставлять без внимания виды, получившие низкие баллы по способности к размножению, но при этом являющиеся редкими и исчезающими.

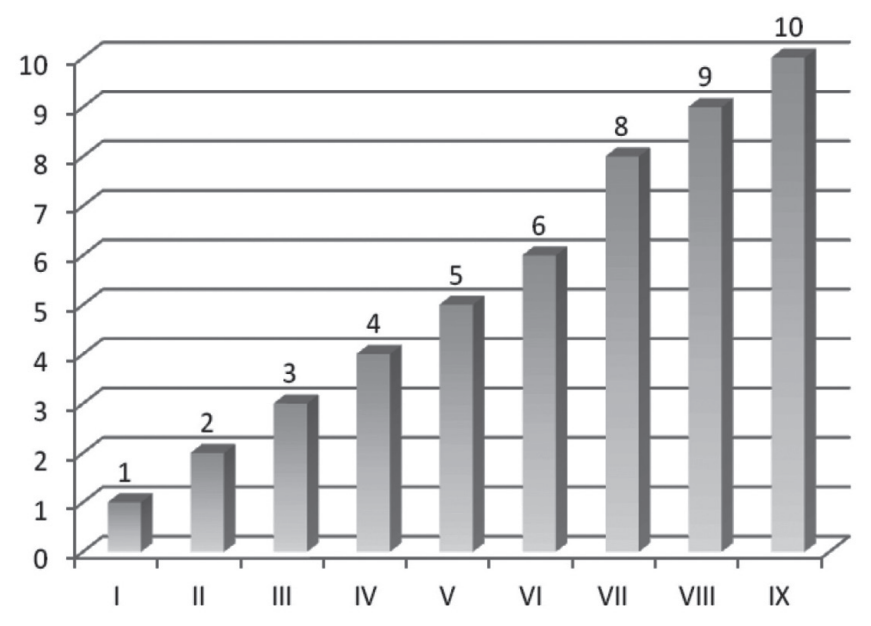

Рис. 5. Состав коллекции видов природной флоры по семействам

Примечания:

I группа - семейства, имеющие в составе 1 вид: Adiantaceae (C. Presl) Ching; Araliaceae Juss.; Aristolochiaceae Juss.; Asparagaceae Juss.; Berberidaceae Juss.; Blechnaceae Newman; Buxaceae Dumort.; Campanulaceae Juss.; Cistaceae Juss.; Dryopteridaceae Herter; Hypericaceae Juss.; Liliaceae Juss.; Lythraceae J. St.-Hil.; Oleaceae Hoffmanna. \& Link; Osmundaceae Martinov; Oxalidaceae R. Br.; Phytolaccaceae R. Br.; Smilacaceae Vent.; Solanaceae Juss.; Thelipteridaceae Ching ex Pic. Serm.; Thymelaeaceae Juss.; Trilliaceae Lindl.; Typhaceae Juss.; Xanthorrhoeaceae Dumort.; Caryophyllaceae Juss.; Colchicaceae DC.; Saxifragaceae Juss.; Violaceae Batsch. II группа - семейства, включающие по 2 вида: Alliaceae J.G. Agardh, Batsch ex Borkh.; Verbenaceae J. St.-Hil.; Araceae Juss.; Aspleniaceae A.B. Frank; Convallariaceae Horan.; Dioscoreaceae R. Br.; Caprifoliaceae Juss.; Geraniaceae Juss.; Paeoniaceae Raf.; Papaveraceae Juss.; Ruscaceae Spreng.; Brassicaceae Burnett. 
Субтропическое и декоративное садоводство (77)

III группа - семейства, насчитывающие по 3 вида:

Cyperaceae Juss.; Apiaceae Lindl.; Apocynaceae Juss.; Scrophulariaceae Juss.

IV группа охватывает семейства, содержащие по 4 вида:

Rosaceae Juss.; Boraginaceae Juss.; Hyacinthaceae Linnaeus; Poaceae Barnhart.

V группа - семейства, имеющие в составе по 5 видов:

Amaryllidaceae J. St.-Hil.; Ranunculaceae Juss.

VI группа - семейство Primulaceae Vent. с 6 видами.

VII группа - семейство Orchidaceae Juss., насчитывающее 8 видов.

VIII группа - семейства, включающие по 9 видов:

Iridaceae Juss.; Lamiaceae Martinov.

IX группа - семейства, имеющие в составе 10 видов:

Crassulaceae J. St.-Hil.; Asteraceae Bercht. \& J.Presl.

Коллекция фрезии включает 47 сортов (в том числе 15 иностранных и 32 созданных в Центре), одну синюю расу, 108 гибридных форм и 35 комбинаций гибридных сеянцев. Сортообразцы разнообразны по окраске (рис. 6). В 2020 г. выделено и проведено описание 6 перспективных форм, в Государственную комиссию РФ по испытанию и охране селекционных достижений переданы документы на новую гибридную форму фрезии с условным названием 'Наталья'. Коллекция пополнена голландским сортом 'Morning sun'.

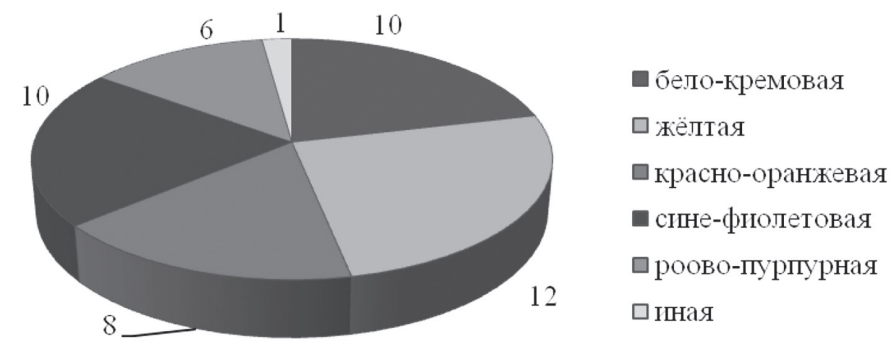

Рис. 6. Состав коллекции фрезии по окраске

Коллекция семейства Ranunculaceae (рис. 7) включает 23 сортов анемоны корончатой (8 зарубежных и 15 селекции Центра), два - анемоны нежной (Anemone blanda Schott \& Kotschy), четыре - анемоны хубейской (Anemone hupehensis (Lemoine) Lemoine) и гибридная форма, три сортопопуляции ранункулюса азиатского (Ranunculus asiaticus Z.). В 2020 г. коллекция пополнилась белой сортопопуляцией ранункулюса азиатского.

Коллекция гемерокаллиса (Hemerocallis $\times$ hybrida Hort.), состоит из 8 сортов и 420 гибридных форм. В 2020 г. коллекция пополнена сортом 'Ed Brown'.

Коллекция почвопокровных растений класса Liliopsida, представленных видами и сортами родов Лириопа (Liriope Lour) и Офиопогон (Ophiopogon 
Глава 1. Общие вопросы

Ker Gawl.), была сохранена в полном объёме: 7 видов, 3 садовые формы рода Liriope Lour и 12 видов, 3 садовые формы рода Ophiopogon Ker Gawl., а также 8 образцов с неустановленной видовой принадлежностью.

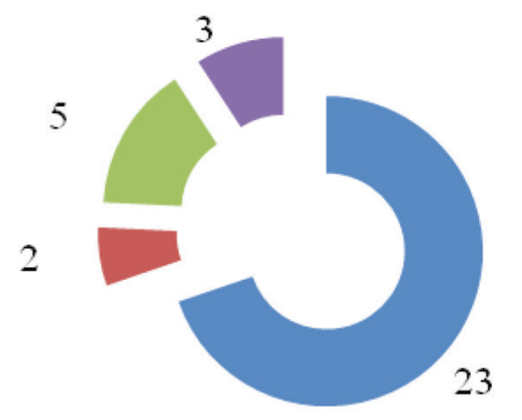

\author{
$\square$ Anemone coronaria \\ -Anemone blanda \\ Anemone hupehensis \\ - Ranunculus asiaticus
}

Рис. 7. Состав коллекции Ranunculaceae

Коллекция хризантемы садовой сохранена в количестве 65 сортообразцов отечественной и зарубежной селекции (рис. 8), из которых доля крупноцветных сортов составляет - $63 \%$, мелкоцветных $-32 \%$, и группа для озеленения - 6 \%.

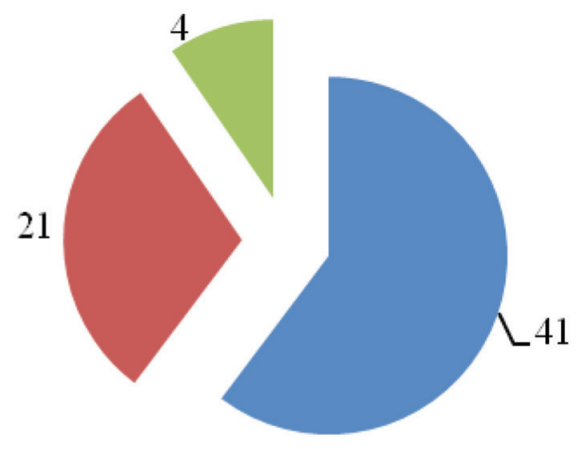

\author{
- Крупноцветные \\ хризантемы \\ п Мелкоцветные \\ хризантемы \\ п Декоративные \\ хризантемы
}

Рис. 8. Состав коллекции хризантемы

В 2020 г. в сортоизучении хризантем участвовало 15 крупноцветных и 15 мелкоцветных сортов. В результате проведённых исследований выделены сорта с ранним цветением (крупноцветные - 'Гагарин', 'Бигуди Пепл', 'Гилберт Лей Сильвер' и 'Изетка Берштейна'; мелкоцветные - 'Нежность', ‘Балун', 'Вестлэнд Регал'. Выделены сорта с длительным периодом цветения 'Нежность' - 49, 'Николина' - 44, 'Бигуди Пепл’ - 43, 'Гагарин' - 42, ‘Зембла Уайт’ - 40 дней. 
Генофонд многолетних цветочных культур, декоративных кустарников, лиан, редких экзотических и эндемичных растений в ботаническом саду «Дерево Дружбы» насчитывает 181 образец. Коллекция пополнена двумя представителями семейства Crassulaceae: Cotyledon orbiculata L. и Kalanchoe millotti Raym-Hamet \& H. Pe.

Коллекция красивоцветущих кустарников представлена 120 сортообразцами (рис. 9): Chaenomeles (8); Forsythia (9); Weigela $\times$ wagneri (23); Hibiscus syriacus (40) и Hydrangea macrophylla (40). В текущем году коллекция пополнилась высокодекоративными сортами Hydrangea L.: 'Hornli', 'Blaumeise', 'Freudenstein', 'Sibilla'.

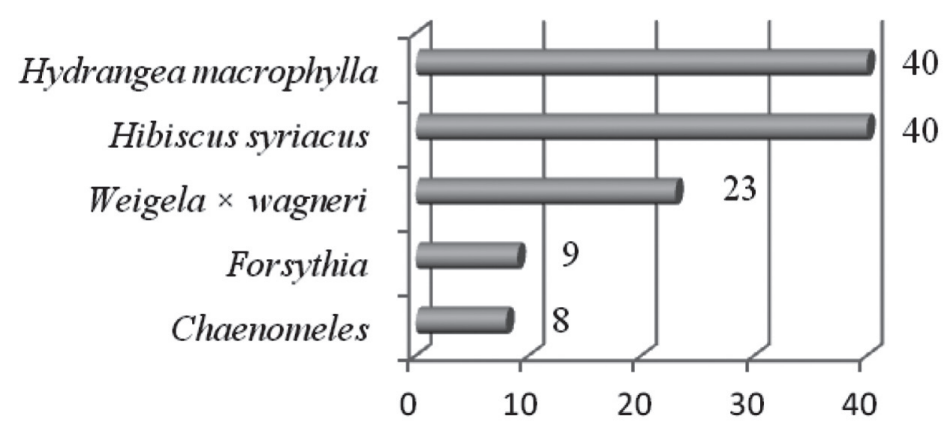

Рис. 9. Состав коллекции красивоцветущих кустарников

В результате изучения фенофаз красивоцветущих кустарников сорта были распределены на группы по срокам цветения (табл. 3).

Состав коллекции многолетних травянистых цветочных культур (табл. 4) насчитывает 34 сортообразца, из которых 13 пионов, 10 гербер, 5 канн, по 2 гипсофилы, агапантуса и астры.

Таблица 3

Группы красивоцветущих кустарников по срокам цветения

\begin{tabular}{|c|c|c|c|}
\hline Культура & Ранний & Средний & Поздний \\
\hline 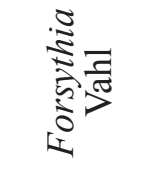 & $\begin{array}{c}\text { 'Kosteriana } \\
\text { variegata' } \\
\text { (c I декады мая) }\end{array}$ & & $\begin{array}{c}\text { 'Beatrix Farrand', } \\
\text { 'Parkdekor', 'Vitellina', } \\
\text { 'Golden Times' } \\
\text { (с III декады марта) }\end{array}$ \\
\hline 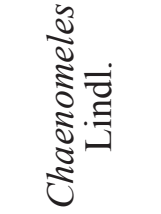 & $\begin{array}{l}\text { 'Afterglow', } \\
\text { 'Ernst Finken' } \\
\text { (c III декады } \\
\text { января) }\end{array}$ & $\begin{array}{c}\text { 'Coral Beauty', } \\
\text { 'Brilliant', 'Red } \\
\text { Trail' } \\
\text { (со II декады } \\
\text { февраля) }\end{array}$ & $\begin{array}{c}\text { 'Crimson and Gold' } \\
\text { (с III декады } \\
\text { февраля) }\end{array}$ \\
\hline
\end{tabular}


Глава 1. Общие вопросы

\begin{tabular}{|c|c|c|c|}
\hline 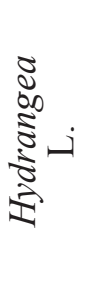 & $\begin{array}{c}\text { 'Harlequin', 'Coco', } \\
\text { 'Intermedia', } \\
\text { 'Twilight', } \\
\text { 'Madame Emile } \\
\text { Mouillere' } \\
\text { (с I декады июня) }\end{array}$ & $\begin{array}{l}\text { 'Alpengluchen', } \\
\text { 'Merville } \\
\text { Sanguine', } \\
\text { 'Selma', 'Green } \\
\text { Shadows' } \\
\text { (со II декады } \\
\text { июня) }\end{array}$ & \\
\hline 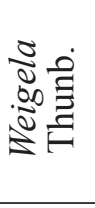 & $\begin{array}{l}\text { ‘Arlequin', } \\
\text { 'Gustave Malet', } \\
\text { 'Mon Blanc’ } \\
\text { (со II декады } \\
\text { апреля) }\end{array}$ & $\begin{array}{l}\text { 'Eva Ratke', } \\
\text { 'Lacepede', } \\
\text { 'Ballet' } \\
\text { (c III декады } \\
\text { апреля) }\end{array}$ & $\begin{array}{c}\text { 'Kosteriana variegata' } \\
\text { (с I декады мая) }\end{array}$ \\
\hline 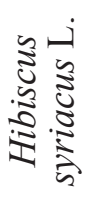 & $\begin{array}{c}\text { ‘Rubis', ‘Blue Bird’ } \\
\text { (со II декады } \\
\text { июня) }\end{array}$ & $\begin{array}{l}\text { 'Dorothy Crane', } \\
\text { 'Pink Giant', } \\
\text { 'Woodbridge' } \\
\text { (с III декады } \\
\text { июня) }\end{array}$ & $\begin{array}{c}\text { 'Dac de Brabant', } \\
\text { 'Matilda' } \\
\text { (co II декады июля) }\end{array}$ \\
\hline
\end{tabular}

Таблииа 4

Состав коллекции многолетних цветочных культур ФИЦ СНЦ РАН

\begin{tabular}{|c|c|}
\hline Род & Количество сортообразцов, шт. \\
\hline Paeonia L. & 13 \\
\hline Gerbera jamesonii Bolus ex Hook.f. & 10 \\
\hline Aster L. & 2 \\
\hline Agapanthus africanus (L.) Hoffmanns. & 2 \\
\hline Gypsophila L. & 2 \\
\hline Canna L. & 5 \\
\hline ВСЕГО & 34 \\
\hline
\end{tabular}

Таким образом, в ФИЦ СНЦ РАН сохранена геноресурсная коллекция субтропических, южных плодовых и цветочно-декоративных культур в количестве 2650 сортообразцов. В результате исследований, проведённых в 2020 г. на различных коллекциях плодовых культур выделены группы по срокам созревания. Цветочно-декоративные культуры представлены в родовом и видовом разрезе, сгруппированы по срокам цветения, окраске цветка. Решение поставленных задач даст возможность дальнейшему развитию отечественного садоводства и цветоводства, позволит расширить вопросы продовольственной безопасности и импортозамещения.

Публикация подготовлена в рамках реализачии ГЗ ФИЦ СНЦ РАН № 0492-2021-0008 


\section{Библиографический список}

1. Беседина Т.Д., Тутберидзе Ц.В., Киселева Н.С. Научно-обоснованный сортимент возделывания актинидии деликатесной во влажных субтропиках России // Плодоводство и ягодоводство России. - 2019. - Т. 59. - С. 108. - ISSN 2073-4948.

2. Беседина Т.Д., Тутберидзе Ц.В., Тория Г.Б. Возможности расширения ареала актинидии деликатесной на Черноморском побережье России // Новые и нетрадиционные растения и перспективы их использования. - 2018. - № 13. - С. 493-495.

3. Бударин А.А., Клемешова К.В. Коллекция роз во Всероссийском научно-исследовательском институте цветоводства и субтропических культур // Плодоводство и ягодоводство России. - 2016. - Т. 47. - С. 53-56. - ISSN 2073-4948.

4. Бударин А.А., Клемешова К.В. Плетистые розы в коллекции Всероссийском научно-исследовательском институте цветоводства и субтропических культур // Субтропическое и декоративное садоводство. - 2020. - Вып. 74. - С. 16-25. - doi: 10.31360/2225-3068-2020-74-16-25.

5. Горшков В.М., Фогель В.А., Кулян Р.В. Каталог цитрусовых культур коллекция ГНУ ВНИИЦИСК Россельхозакадемии. - Сочи: ВНИИЦиСК, 2013. - Вып. 2. - 91 с. ISBN 978-5-904533-17-5.

6. Гутиева Н.М. Адаптивный ассортимент многолетних цветочных культур для вертикального озеленения в зоне влажных субтропиков России. // Субтропическое и декоративное садоводство. - 2012. - Вып. 46. - С. 34-41. - ISSN 2225-3068.

7. Гутиева Н.M. Признаковая коллекция рода Pelargonium // Плодоводство и ягодоводство России. - 2018. - Т. 54. - С. 31-34. - doi: 10.31676/2073-4948-2018-54-31-34.

8. Инденко И.Ф. Интродукция и селекция сортов яблони, иммунных к парше и толерантных к мучнистой росе в горных условиях Западного Кавказа // Субтропическое и декоративное садоводство. - 2012. - Вып. 47. - С. 89-94. - ISSN 2225-3068.

9. Киселёва Н.С. Анализ изменчивости признаков продуктивности в коллекции груши // Субтропическое и декоративное садоводство. - 2016. - Вып. 58. - С. 44-50. ISSN 2225-3068.

10. Киселева Н.С. Оценка коллекционных сортов и гибридов груши по степени устойчивости к повышенным температурам летнего периода методом флуктуирующей асимметрии // Субтропическое и декоративное садоводство. - 2019. - Вып. 68. - C. 63-71. - doi: 10.31360/2225-3068-2019-68-63-71.

11. Клемешова К.В., Бударин А.А., Карпун Н.Н. Методика комплексной оценки декоративности садово-парковых роз из функциональных групп многоцветковые и почвопокровные в условиях влажных субтропиков России // Субтропическое и декоративное садоводство. - 2020. - Вып. 73. - С. 96-111. - doi: 10.31360/22253068-2020-73-96-111.

12. Клемешова К.В., Габуева Т.Ю. Сезонные ритмы развития Chrysanthemum × hortorum Bailey на Черноморском побережье Краснодарского края // Научные труды Чебоксарского филиала ГБС РАН, 2020. - Вып. 15. - С. 107-112.

13. Клемешова К.В., Габуева Т.Ю. Сорта Chrysanthemum $\times$ hortorum Вailey в условиях влажных субтропиков России // Субтропическое и декоративное садоводство. - 2020. - Вып. 73. - C. 43-50. - doi: 10.31360/2225-3068-2020-73-43-50.

14. Клемешова К.В., Яшмурзина Д.С. Состояние коллекции тропических и субтропических видов в зимнем саду ВНИИЦиСК // Субтропическое и декоративное садоводство. - 2018. - Вып. 65. - С. 195-202. - ISSN 2225-3068.

15. Козина В.В., Козина С.В. Коллекция рода Anemone L. в условиях влажных субтропиков // Субтропическое и декоративное садоводство. - 2018. - Вып. 66. - С. 47-57. - ISSN 2225-3068.

16. Козина В.В., Слепченко Н.А. Коллекция ирисов во влажных субтропиках России // Вестник Мичуринского государственного аграрного университета. - 2015. - № 3. - С. 60-67. 
17. Козина С.В. Анемона нежная в условиях влажных субтропиков России // Субтропическое и декоративное садоводство. - 2020. - Вып. 72. - С. 39-45. doi: 10.31360/2225-3068-2020-72-39-45.

18. Коннов Н.А. Технология возделывания представителей рода Liriope Lour. в условиях Черноморского побережья России // Субтропическое и декоративное садоводство. - 2015. - Вып. 55. - С. 113-120. - ISSN 2225-3068.

19. Коннов Н.А., Карпун Н.Н., Келина А.В. Засухоустойчивость Liriope graminifolia (L.) Baker и Ophiopogon japonicus (Thunb.) Ker Gawl. - перспективных газонообразующих растений для субтропической зоны Черноморского побережья России // Садоводство и виноградарство. - 2020. - № 4. - С. 18-24. - doi: 10.31676/0235-2591-2020-4-18-24.

20. Кулян Р.В. Формирование и изучение коллекции мандарина для селекционного использования // Научные труды Северо-Кавказского федерального научного центра садоводства, виноградарства, виноделия. - 2019. - Т. 25. - С. 114-117. doi: 10.30679/2587-9847-2019-25-114-117.

21. Кулян Р.В., Иваненко Ф.К., Ксенофонтова Д.В. Новые сорта Asimina triloba (L.) Dunal (Азимина трёхлопастная) для субтропиков России // Плодоводство и ягодоводство России. - 2015. - Т. XXXXI. - № 2. - С. 223-227. - ISSN 2073-4948.

22. Лобова Т.Е., Слепченко Н.А. К вопросу возделывания нерины боудена и амариллиса белладонна на Черноморском побережье России // Субтропическое и декоративное садоводство: сб. науч. тр. - Сочи: ВНИИЦиСК, 2010. - Вып. 43. - Т. II. - С. 59-63. 23. Лошкарёва С.В. Морфобиологическая оценка сортообразцов чая во влажных субтропиках России // Новые технологии. - 2017. - № 4. - С. 113-118. - ISSN: 2072-0920. 24. Маляровская В.И. Перспективные красивоцветущие кустарники на Черноморском побережье Краснодарского края // Субтропическое и декоративное садоводство. - 2016. - Вып. 56. - С. 58-64. - ISSN 2225-3068.

25. Маляровская В.И., Солтани Г.А., Кунина В.А. Морфо-биологическая характеристика представителей рода Forsythia Vahl в условиях влажных субтропиков России [Электронный ресурс] // Плодоводство и виноградарство Юга России. 2020. - № 65(5). - C. 340-353. - doi: 10.30679/2219-5335-2020-5-65-340-353.

26. Омаров М.Д., Кулян Р.В., Омарова 3.М. Хурма восточная в коллекции ВНИИЦиСК - основа для выделения источников хозяйственно-ценных признаков // Плодоводство и ягодоводство России. - 2018. - Т. 55. - С. 46-53. - ISSN 2073-4948.

27. Омаров М.Д., Омарова 3.M. Сорта хурмы восточной (Diospyros kaki L.) и их биологические особенности // Субтропическое и декоративное садоводство. - 2016. Вып. 57. - С. 69-72. - ISSN 2225-3068.

28. Омарова 3.М. Культура фейхоа в субтропиках России // 110 лет в субтропиках России: сб. науч. тр. - Сочи: ВНИИЦиСК, 2004. - Вып. 39. - Ч. II. - С. 350-361.

29. Омарова 3.М. Перспективные формы фейхоа для Черноморского побережья РФ // Садоводство и виноградарство. - 2014. - № 6. - С. 6-8. - ISSN 0235-2591.

30. Пащенко О.И. Гемерокаллис гибридный (Hemerocallis $\times$ hybrida Hort.) в коллекции Всероссийского научно-исследовательского института цветоводства и субтропических культур // Субтропическое и декоративное садоводство. - 2017. - Вып. 60. - С. 43-48. - ISSN 2225-3068.

31. Пащенко О.И. Коллекция фрезии гибридной во ВНИИЦиСК и перспективы её расширения // Hortus botanicus. - 2017. - Т. 12. - doi: 10.15393/j4.art.2017.4702.

32. Пащенко О.И. Фрезия - технология срезочной культуры и использование во флористике // Субтропическое и декоративное садоводство. - 2016. - Вып. 56. - С. 117-121. - ISSN 2225-3068. 
33. Программа Северо-Кавказского центра по селекции плодовых, ягодных, цветочно-декоративных культур и винограда на период до 2030 года. - Краснодар. 2013. 202 с. - ISBN 972-5-982720-96-2.

34. Рындин А.В., Гутиева Н.И. Уникальный сад «Дерево Дружбы» // Цветоводство. 2014. - № 2. - С. 10-13. - ISSN 0041-4905.

35. Рындин А.В. Агроэкологические аспекты садоводства влажных субтропиков России. - Сочи: ВНИИЦиСК, 2016. - 260 с. - ISBN 978-5-904533-29-8.

36. Рындин А.В. Генетические ресурсы субтропических, южных плодовых, цветочнодекоративных культур и возможности их использования. Государственное научное учреждение Всероссийский научно-исследовательский институт цветоводства и субтропических культур Россельхозакадемии // Плодоводство и ягодоводство России. 2009. - Т. 22. - № 1. - C. 118-128. - ISSN 2073-4948.

37. Рындин А.В. и др. Коллекция субтропических плодовых, орехоплодных (кроме Juglans и Corylus), масленичных и пряно-вкусовых растений Российской Федерации, Республики Абхазия и Республики Беларусь. - Сочи: ВНИИЦиСК. - 2019. - 167 с. ISBN 978-5-904533-31-1.

38. Рындин А.В., Горшков В.М., Кулян Р.В., Карпун Н.Н., Игнатова Е.А., Сабекия Д.А. Любительское цитрусоводство. - Сочи: ВНИИЦиСК, 2016. - 130 с. - ISBN 978-5-904533-26-7. 39. Рындин А.В., Кулян Р.В. Коллекция унаби (Zizyphus jujuba Mill.) во влажных субтропиках России // Садоводство и виноградарство. - 2017. - № 6. - С. 36-41. - ISSN 0235-2591.

40. Рындин А.В., Кулян Р.В. Коллекция цитрусовых культур во влажных субтропиках России // Садоводство и виноградарство. - 2016. - № 5. - С. 24-30. - ISSN 0235-2591. 41. Рындин А.В., Маляровская В.И., Карпун Ю.Н., Солтани Г.А., Кунина В.А., Тыщенко Е.Л., Кувайцев М.В. Красивоцветущие кустарники на юге России (хеномелес, форсайтия, вейгела, гидрангея, гибискус). - Сочи: ФИЦ СНЦ РАН, 2020. - ISBN 978-5-904533-41-0.

42. Рындин А.В., Слепченко Н.А. Цветочно-декоративные культуры в ФГБНУ ВНИИЦиСК: состояние и пополнение коллекций // Научные труды Северо-Кавказского федерального научного центра садоводства, виноградарства, виноделия. - 2019. - T. 25. - C. 206-210. - doi: 10.30679/2587-9847-2019-25-206-210.

43. Рындин А.В., Слепченко Н.А., Лобова Т.Е. Нарциссы в субтропиках России. Сочи: ФИЦ СНЦ РАН, 2020. - 105 с. - ISBN 978-5-904533-38-0.

44. Рындин А.В., Смагин Н.Е., Абильфазова Ю.С. Перспективные сорта персика для влажных субтропиков России (Сочи) // Субтропическое и декоративное садоводство. - 2011. - Вып. 44. - С. 119-124. - ISSN 2225-3068.

45. Слепченко К.В., Загудаева Ю.С. Осеннецветущие Амариллисовые в условиях влажных субтропиков России // Субтропическое и декоративное садоводство. - 2020. - Вып. 75. - С. 33-38. - doi: 10.31360/2225-3068-2020-75-33-38.

46. Слепченко Н.А. Из опыта оценки декоративности мелколуковичных культур на примере крокусов // Плодоводство и ягодоводство России. - 2020. - Т. 63. - С. 146154. - doi: 10.31676/2073-4948-2020-63-146-154.

47. Слепченко Н.А. Новые подходы к методике изучения низкорослых мелколуковичных культур // Современные методология, инструментарий оценки и отбора селекционного материала садовых культур и винограда. - Краснодар: СКЗНИИСиВ, 2017. - С. 277-282.

48. Слепченко Н.А. Оценка декоративности сортов Iris sibirica в условиях влажных субтропиков России // Научные труды Северо-Кавказского федерального научного центра садоводства, виноградарства, виноделия. - 2019. - Т. 25. - С. 211 214. - doi 10.30679/2587-9847-2019-25-211-214.

49. Слепченко Н.А. Разрезнокорончатые нарциссы в коллекции ФИЦ СНЦ РАН // Субтропическое и декоративное садоводство. - 2020. - Вып. 74. - С. 40-47. - doi: 10.31360/2225-3068-2020-74-40-47. 
50. Слепченко Н.А. Редкие и исчезающие виды орхидей в коллекции ФИЦ СНЦ РАН // Ботанические сады как центры изучения и сохранения фиторазнообразия: труды Междунар. науч. конференция, посвященной 140-летию Сибирского ботанического сада Томского государственного университета, г. Томск, 28-30 сентября 2020 г. - Томск: Изд-во Томского гос. Университета, 2020. - С. 170172. - doi: 10.17223/978-5-94621-956-3-2020-54.

51. Слепченко Н.А. Сохранение редких и исчезающих видов луковичных растений во Всероссийском научно-исследовательском институте цветоводства и субтропических культур // Проблемы ботаники Южной Сибири и Монголии. - 2019. - 1(18). - С. 618 622. - doi: 10.14258/pbssm.2019130.

52. Слепченко Н.А., Слепченко К.В. Изучение декоративности сортообразцов Iris sibirica в условиях влажных субтропиков России // Субтропическое и декоративное садоводство. - 2020. - Вып. 75. - С. 28-33. - doi: 10.31360/2225-3068-2020-75-28-33.

53. Смагин Н.Е., Абильфазова Ю.С. Интродуцированные сорта персика во влажных субтропиках России // Субтропическое и декоративное садоводство. - 2017. - Вып. 62. - С. 106-111. - ISSN 2225-3068.

54. Туов М.Т., Рындин А.В. Итоги изучения перспективных гибридов чая в субтропиках Российской Федерации // Субтропическое и декоративное садоводство. - 2012. - Вып. 46. - С. 114-122. - ISSN 2225-3068.

55. Тутберидзе Ц.В. Декоративные сорта алычи // Декоративное садоводство России: сб. науч. тр. - Сочи: ВНИИЦиСК, 2008. - Вып. 41. - С. 371-374.

56. Тутберидзе Ц.В. Новые сорта актинидии во влажных субтропиках России // Субтропическое и декоративное садоводство. - 2018. - Вып. 67. - С. 113-118. - ISSN 2225-3068.

57. Яшмурзина Д.С., Козина Е.В. Анализ изменений в составе и структуре семейства Asparagaceae Juss. на примере видов, применяемых в озеленении зимнего сада ВНИИЦиСК // Субтропическое и декоративное садоводство - 2019. - Вып. 68. C. 85-93. - ISSN 2225-3068.

\title{
THE RESULTS OF INTRODUCTION OF SUBTROPICAL, SOUTHERN FRUIT AND FLOWER-ORNAMENTAL CROPS IN FRC SSC OF RAS
}

\author{
Ryndin A. V., Kulyan R. V., Slepchenko N. A., Tutberidze Ts. V., Gorshkov V. M. \\ Federal Research Centre \\ the Subtropical Scientific Centre of the Russian Academy of Sciences, \\ Sochi,Russia,e-mail: slepchenko@vniisubtrop.ru
}

The paper presents the results of research carried out in the Federal Research Centre the Subtropical Scientific Centre of the Russian Academy of Sciences on such themes as mobilization, preservation and study of genetic bioresource collections. The gene resource collection of subtropical, southern fruit and flower-ornamental crops has been preserved in the amount of 2650 cultivars. As a result of the research carried out in 2020 on various collections of fruit crops, the groups were identified by ripening periods. Flower-ornamental crops are presented in a generic and specific section, grouped by flowering terms and flower colour. Solving the given tasks will enable the further development of domestic horticulture and floriculture, as well as will expand the issues of food security and import substitution.

Key words: introduction, cultivar study, genetic resource collection, subtropical, southern fruit and flower-ornamental crops. 